\title{
Evaluation of Nosocomial Infections and Antimicrobial Resistance Profiles in the Intensive Care Units: Nine Years Experience
}

\section{Yoğun Bakım Ünitesinde Nozokomiyal Enfeksiyonlar ve Antimikrobiyal Direnç Profillerinin Değerlendirilmesi: Dokuz Yıllık Deneyim}

(D) Ayşegül KESKIN SEREMET, iD Filiz KIZILATEŞ, iD Kübra DEMIR ÖNDER, iD Nefise ÖZTOPRAK

University of Health Sciences Turkey, Antalya Training and Research Hospital, Clinic of Infectious Diseases and Clinical Microbiology,

Antalya, Turkey

\section{ABSTRACT}

Objective: The aim of this study is to identify nosocomial infections and causative mikroorganisms in adult intensive care units of hospital and also to investigate the changes in antimicrobial resistance profiles over a nine-year period.

Methods: The infection control committee surveillance data of 29318 patients hospitalized in adult intensive care units between 01 January 2010 and 31 December 2018 were evaluated retrospectively.

Results: A total of 29318 patients were followed up in adult intensive care units of hospital in nine-year period and nosocomial infection was detected in 2593 patients $(8.8 \%)$. The most common infections were; ventilator-associated pneumonia $(34.1 \%)$, catheter-related urinary tract infection (21.8\%), primary bacteremia (17.1\%), central venous catheter-related bloodstream infection (14.7\%) and pneumonia (8.5\%). The most common causative agents were Gramnegative bacteria $(72.9 \% ; 2056 / 2822)$. Carbapenem resistance in gram negative bacteria responsible for nosocomial infections was $33 \%$ in 2010 and reached $75 \%$ in 2018 . Colistin resistance of Klebsiella spp. strains reached up to $34 \%$ in 2018.

Conclusion: In Turkey, nosocomial infections in intensive care units are an important problem as well as in the world. With increasing antibiotic resistance, treatment of infections is becoming difficult. Therefore; each center should follow its own infectious

\section{ÖZ}

Amaç: $\mathrm{Bu}$ çalışmanın amacı, hastanemiz erişkin yoğun bakım ünitelerinde gelişen hastane enfeksiyonlarını ve etken mikroorganizmaları tanımlamak, ve ayrıca dokuz yıllık süreçte antimikrobiyal direnç profillerindeki değişimi araştırmaktır.

Yöntemler: 01 Ocak 2010-31 Aralık 2018 tarihleri arasında erişkin yoğun bakım ünitelerinde yatan 29318 hastanın enfeksiyon kontrol komitesi sürveyans verileri retrospektif olarak değerlendirildi.

Bulgular: Hastanemiz erişkin yoğun bakım ünitelerinde toplam 29318 hasta takip edildi, bunların 2593'ünde $(\% 8,8)$ nozokomiyal enfeksiyon gelişti. En sık görülen hastane enfeksiyonları sırası ile ventilatör ilişkili pnömoni $(\% 34,1)$, kateter ilişkili üriner sistem enfeksiyonu $(\% 21,8)$, primer bakteremi $(\% 17,1)$, santral venöz kateter ilişkili kan dolaşımı enfeksiyonu $(\% 14,7)$ ve pnömoni $(\% 8,5)$ idi. Nozokomiyal enfeksiyon etkeni olarak en sık gram negatif bakteriler (\%72,9; 2056/2822) izole edildi. Nozokomiyal enfeksiyonlardan sorumlu olan gram negatif bakterilerde karbapenem direncinin 2010 yılında \%33 iken 2018 yılında \%75’e ulaştığı saptandı. Kolistin direncinin ise 2018 yılında Klebsiella spp. suşlarında \%34'e kadar ulaştığı tespit edildi.

Sonuç: Yoğun bakım ünitelerinde gelişen nozokomiyal enfeksiyonlar tüm dünyada olduğu gibi Türkiye'de de önemli bir sorundur. Artan antibiyotik direnci ile enfeksiyonların tedavisi giderek
Address for Correspondence: Ayşegül KESKIN SEREMET, University of Health Sciences Turkey, Antalya Training and Research Hospital, Clinic of Infectious Diseases and Clinical Microbiology, Antalya, Turkey E-mail: aseremetkeskin@yahoo.com ORCID ID: orcid.org/0000-0002-9224-4699

Cite this article as: Keskin Seremet A, Kızılateş F, Demir Onder K, Oztoprak N. Evaluation of Nosocomial Infections and Antimicrobial Resistance Profiles in the Intensive Care Units: Nine Years Experience. Bezmialem Science 2020;8(4):330-337.

${ }^{\circ}$ Copyright 2020 by the Bezmiâlem Vakıf University

Bezmiâlem Science published by Galenos Publishing House.
Received: 28.06.2019

Accepted: 05.11.2019 
agent distribution and antibiotic susceptibility, empirical treatment should be selected appropriate to the flora of the intensive care unit and the broad use of broad spectrum antibiotics should be limited.

Keywords: Antibiotic resistance, nosocomial infections, intensive care unit zorlaşmaktadır. Bu nedenle; her merkezin kendi etken dağılımı ve antibiyotik duyarlılıklarını takip etmesi, empirik tedavide yoğun bakım ünitesinin florasına uygun antibiyotik seçilmesi ve geniş spektrumlu antibiyotiklerin yaygın kullanımının kısıtlanması gereklidir.

Anahtar Sözcükler: Antibiyotik direnci, hastane enfeksiyonları, yoğun bakım

\section{Introduction}

Patients who are followed up and treated in intensive care units (ICUs) in hospitals are at risk for the development of nosocomial infections due to the long hospitalization period and invasive procedures such as intubation, mechanical ventilation, tracheostomy and urinary catheterization (1).

Nosocomial infection (NI) is defined as the infection that develops 48-72 hours after the patient's hospitalization (2). While pneumonia is the most common NI in ICUs, urinary infections are in the first order in hospital units other than ICU (3). At least one antibiotic is given to an average of $80 \%$ of the patients in the ICU $(4,5)$. Therefore, ICUs are hospital units with the highest antibiotic resistance. The distribution of microorganisms that cause NI varies between units of the hospital as well as between different centers.

Increasing resistance against antibiotics creates a problem in the selection of empirical treatment of critically ill patients, especially those in the ICU. Infections caused by multi-antibiotic resistant microorganisms cause an increase in morbidity and mortality, prolongation of hospital stay, an increase in costs and the emergence of serious complications (6).

It is only possible to determine the frequency of NI and the distribution of agents, to detect developing epidemics, to evaluate whether infection control measures are applied effectively, and to monitor the infection rates of our hospital, with continuous and effective infection surveillance. Surveillance studies are guiding in identifying real problems and evaluating the effectiveness of infection control policies (7).

In this study, we aimed to examine the developing nosocomial infections, causative microorganisms and antimicrobial resistance profiles in the ICUs of our hospital between January 2010 and December 2018.

\section{Method}

Our hospital is a tertiary training and research hospital serving an average of 71767 inpatients and an average of 5278 ICU patients in a year. Until 2016, adult ICU had consisted of 4 separate units and 49 beds in total; after 2016, it started to serve with 9 units and a total of 83 beds. Active, patient and laboratory-based surveillance is carried out by the Infection Control Committee (ICC) in ICUs in our hospital. Surveillance data are evaluated by the infection control physician and the infection control nurse.
In our study, the ICC surveillance data of 29318 patients hospitalized in the ICU between January 2010 and December 2018 were retrospectively evaluated. The diagnosis of NI was made based on the definitions of the Ministry of Health National Nosocomial Infections Surveillance Network (UHESA). Typing of the causative microorganisms and their antibiotic susceptibilities were done with the Phoenix automatized system (BD Diagnostic Systems, USA). Infection rate was calculated with the formula (NI number/patient number)X100 and NI Density was calculated with the formula (NI number/patient day)X1000. In the calculation of invasive device-related infection rates, the invasive device-associated NI number/invasive device use day $\times 1000$ formula was used.

The study was approved by the Antalya Training and Research Hospital Ethics Committee (Date: 30-03-2017, number: 6/03).

\section{Results}

In the course of nine years, a total of 29318 patients were followed up in all ICUs, and NE developed in 2593 (8.8\%) of them. The distribution of NI by years is given in Table 1 . When the distribution of NI according to systems was examined; ventilatorassociated pneumonia (VAP) was found the most (34.1\%) in ICUs. The second most common was catheter-associated urinary tract infection (CAUTI) $(21.8 \%)$, followed by primary bacteremia $(17.1 \%)$, central venous catheter-related bloodstream infection (CRBSI) (14.7\%), and pneumonia (8.5\%).

The most common NE agents were gram negative bacteria (2056/2822) with a rate of $72.9 \%$. The distribution of causative microorganisms is given in Table 3 .

Carbapenem resistance in gram-negative bacteria responsible for NI between 2010 and 2018, were found as 33\%, 48\%, 57\%, $46 \%, 52 \%, 68 \%, 60 \%, 72 \%$ and $75 \%$, respectively. The increase in carbapenem resistance among especially in strains of Klebsiella spp. was remarkable. While there was no carbapenem resistance in 2010 , this rate reached $83 \%$ in 2018 (Table 4).

The rate of detection of extended spectrum beta-lactamase (ESBL) in gram-negative bacteria, which were nosocomial infectious agents, was 20\%, 55\%, 41\%, 27\%, 40\%, 38\%, 38\%, $21 \%$ and 27\%, respectively between 2010 and 2018 (Table 5).

It was noteworthy that colistin resistance in strains of Acinetobacter spp., Pseudomonas spp. and Klebsiella spp. which were included in the study increased over the years. Colistin resistance reached up to $34 \%$ in strains of Klebsiella spp. It was 
determined that piperacillin-tazobactam resistance increased in strains of Klebsiella spp. over the years. These high resistance rates cause serious problems in treatment planning and treatment success, especially in infections caused by gram-negative bacteria (Table 6).

Coagulase negative staphylococci constituted the majority of gram positive bacteria which were NI agents. Methicillin resistance was quite high in coagulase-negative staphylococci (100\%, 92\%, 85\%, 95\%, 84\%, 87\%, 88\%, 100\%, 100\%, respectively by years).

Vancomycin resistance was detected in 20 (11.3\%) of a total of 177 Enterococcus strains isolated as NI agents between 20102018 in ICUs. Although vancomycin resistance seemed to increase in recent years, it should be kept in mind that there might be strains naturally resistant to vancomycin such as $\mathrm{E}$. gallinarum in this group (Table 7).

\section{Discussion}

NI increases the length of hospital stay, leading to labor loss and increased treatment costs. Morbidity and mortality rates are higher than other infections. While the incidence of NI is between $3.6 \%$ and $12 \%$ in high-income countries, this rate varies between $5.7 \%$ and $12 \%$ in low and middle-income countries (8).

Prematures and newborns whose immune system is not sufficient, elderlies, those with underlying chronic diseases, those who have undergone an operation, those diagnosed with cancer, traumatic patients, and patients with metabolic disorders constitute the risk group for the development of NI. In addition, longterm follow-up and treatment of patients in the ICU increase the risk of colonization of these patients with microorganisms and subsequent infection development. Multiple antibiotic treatments used because of the high infection rate in the ICU lead to the emergence of resistant microorganisms. As a result, problems arise in empirical antibiotherapy response.

Microorganisms and antibiotic susceptibilities that develop in ICUs differ between countries, regions, hospitals, and even ICUs in the same hospital $(9,10)$. In order to achieve success in NI treatment and to determine the infection control measures that should be applied, it is necessary to continuously monitor the specialized units of the hospital and crowded ICUs for the infections that occur, the microorganisms that cause infections and the antibiotic susceptibility of microorganisms (11). For this

Table 1. Nosocomial infections developing in ICUs between 2010-2018

\begin{tabular}{|c|c|c|c|c|}
\hline & $\begin{array}{l}\text { Number of hospitalized } \\
\text { patients }\end{array}$ & Patient day & $\begin{array}{l}\text { Nosocomial infection } \\
\mathrm{n}(\%)\end{array}$ & $\begin{array}{l}\text { Nosocomial infection } \\
\text { density }\end{array}$ \\
\hline 2010 & 2,295 & 11,051 & $179(7.84)$ & 16.29 \\
\hline 2011 & 2,952 & 12,456 & $144(4.95)$ & 11.72 \\
\hline 2012 & 3,124 & 12,463 & $183(5.86)$ & 14.78 \\
\hline 2013 & 3,178 & 12,561 & $189(5.95)$ & 15.05 \\
\hline 2016 & 2,911 & 14,216 & $436(14.9)$ & 30.6 \\
\hline 2017 & 4,123 & 20,827 & $360(8.7)$ & 17.2 \\
\hline 2018 & 4,645 & 24,721 & $411(8.8)$ & 16.8 \\
\hline Total & 29,318 & 134,806 & $2,593(8.8)$ & 19.2 \\
\hline
\end{tabular}

Table 2. Distribution of nosocomial Infections in ICUs between 2010-2018 by systems

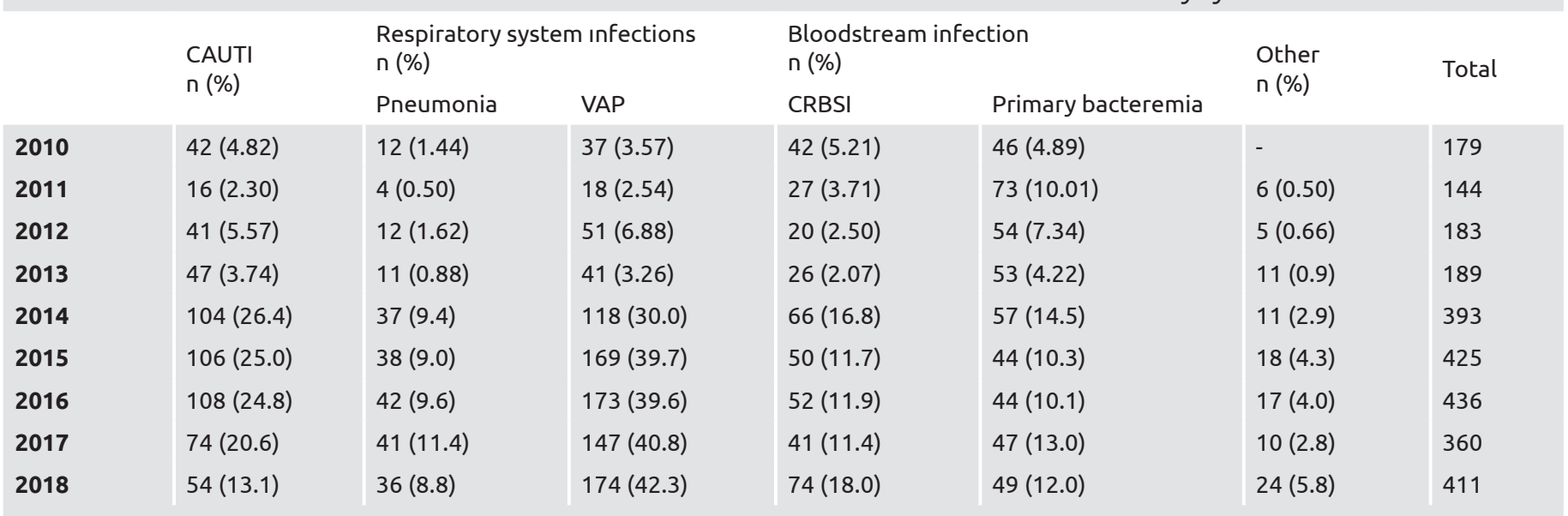

VAP: Ventilator-associated pneumonia, CAUTI: Catheter-associated urinary tract infection, CRBSI: Central venous catheter-related bloodstream infection 
Table 3. Microorganisms causing nosocomial infections in ICUs between 2010-2018

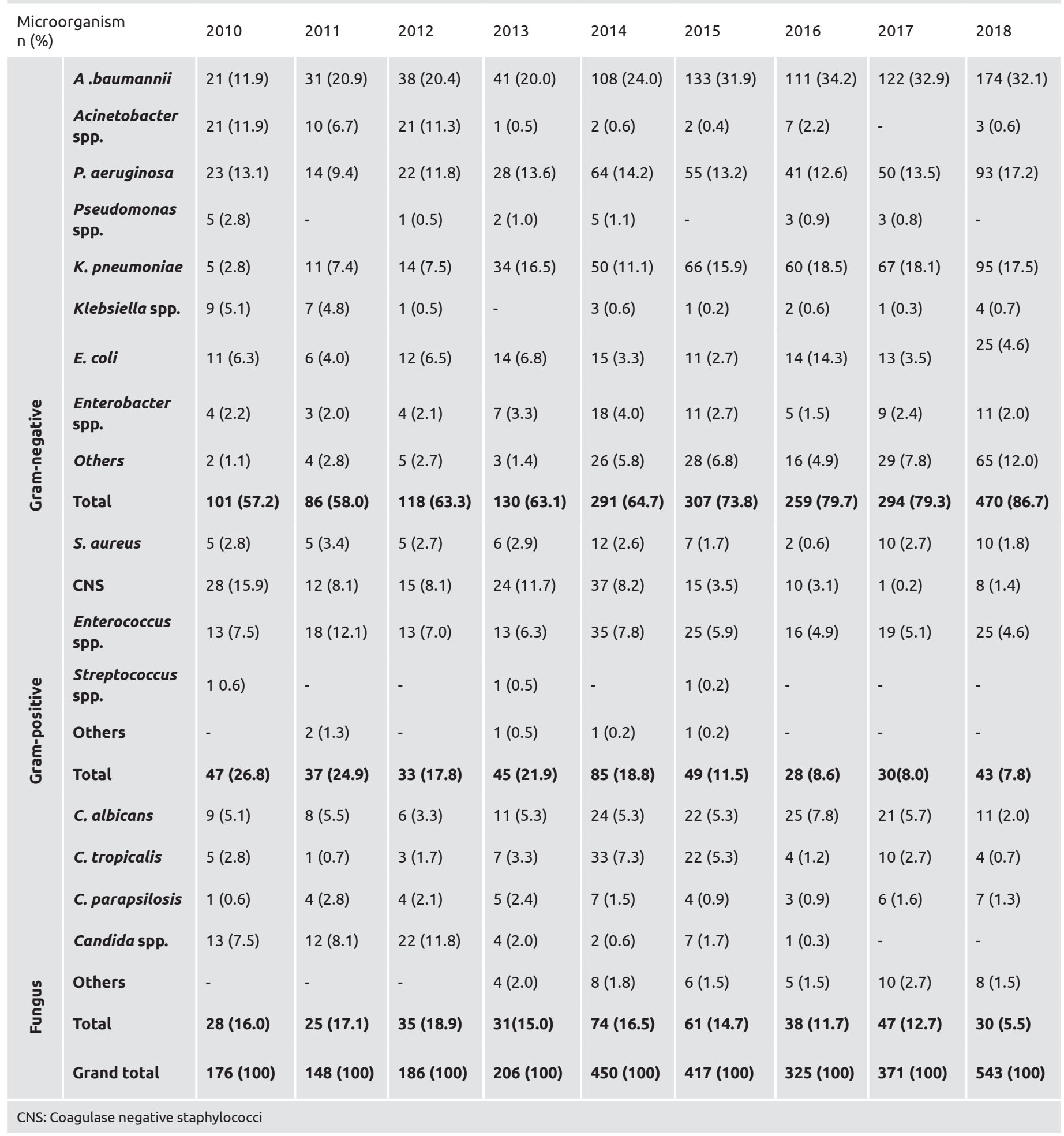

reason, active and patient and laboratory-based surveillance is carried out by ICC in ICUs and specialized units of our hospital, and agent microorganisms and antibiotic susceptibilities are regularly reported to the relevant departments. Defining NIs in ICUs is necessary for determining local epidemiological features and empirical treatment approach (12).
In studies conducted in our country, the NI rate has been reported between 5.3\% and 56.1\% (13). Karahocagil et al. reported the NI rate as $3.5 \%$ throughout the hospital and $18.3 \%$ in the ICU (14). On the other hand, Öncül et al. reported the NE rate as $9.1 \%$ in ICU (15). In our study, we found the rate of NI in the ICU as $8.8 \%$. 
Table 4. Carbapenem resistance in agent microorganisms in ICUs between 2010-2018

\begin{tabular}{|c|c|c|c|}
\hline & & $\begin{array}{l}\text { Total number } \\
\text { of agents }\end{array}$ & $\begin{array}{l}\text { Number of } \\
\text { agents resistant } \\
\text { to carbapenem } \\
\text { (\%) }\end{array}$ \\
\hline \multirow{4}{*}{2010} & A. baumannii & 21 & $19(90)$ \\
\hline & P. aeruginosa & 23 & $3(13)$ \\
\hline & Klebsiella spp. & 9 & - \\
\hline & E. coli & 11 & - \\
\hline \multirow{4}{*}{2011} & A.baumannii & 31 & $29(94)$ \\
\hline & P. aeruginosa & 14 & $3(21)$ \\
\hline & Klebsiella spp. & 18 & $1(6)$ \\
\hline & E. coli & 6 & - \\
\hline \multirow{4}{*}{2012} & A.baumannii & 38 & $38(100)$ \\
\hline & P. aeruginosa & 22 & $11(50)$ \\
\hline & Klebsiella spp. & 15 & $1(7)$ \\
\hline & E. coli & 12 & - \\
\hline \multirow{4}{*}{2013} & A.baumannii & 41 & $37(90)$ \\
\hline & P. aeruginosa & 28 & $11(39)$ \\
\hline & Klebsiella spp. & 34 & $6(18)$ \\
\hline & E. coli & 14 & - \\
\hline \multirow{4}{*}{2014} & A.baumannii & 108 & $96(89)$ \\
\hline & P. aeruginosa & 64 & $23(36)$ \\
\hline & Klebsiella spp. & 53 & $5(9)$ \\
\hline & E. coli & 15 & - \\
\hline \multirow{4}{*}{2015} & A.baumannii & 132 & $121(92)$ \\
\hline & P. aeruginosa & 101 & $51(50)$ \\
\hline & Klebsiella spp. & 67 & $36(54)$ \\
\hline & E. coli & 11 & $3(27)$ \\
\hline \multirow{4}{*}{2016} & A.baumannii & 111 & $92(83)$ \\
\hline & P. aeruginosa & 43 & $13(67)$ \\
\hline & Klebsiella spp. & 62 & $31(50)$ \\
\hline & E. coli & 14 & $1(7)$ \\
\hline \multirow{4}{*}{2017} & A.baumannii & 122 & $113(93)$ \\
\hline & P. aeruginosa & 50 & $18(36)$ \\
\hline & Klebsiella spp. & 68 & $48(71)$ \\
\hline & E. coli & 13 & $4(31)$ \\
\hline \multirow{4}{*}{2018} & A.baumannii & 122 & 113 (93) \\
\hline & P. aeruginosa & 50 & $18(36)$ \\
\hline & Klebsiella spp. & 58 & $48(83)$ \\
\hline & E. coli & 13 & $4(31)$ \\
\hline
\end{tabular}

The most common NI in ICUs is pneumonia $(16,17)$. The most important risk factor for the development of nosocomial pneumonia is intubation and mechanical ventilation. Therefore, VAP constitutes the majority of pneumonia in ICUs. Akın et al. reported the rate of pneumonia as $41 \%$ (18). In our study, the VAP rate was found to be $34.1 \%$.
Table 5. Positivity Rate of Extended Spectrum BetaLactamase (ESBL) in gram-negative microorganisms in ICUs between 2010-2018

\begin{tabular}{|c|c|c|c|}
\hline & & $\begin{array}{l}\text { Total } \\
\text { number } \\
\text { of } \\
\text { agents }\end{array}$ & $\begin{array}{l}\text { Number of } \\
\text { agents with } \\
\text { GSBL (\%) }\end{array}$ \\
\hline \multirow{3}{*}{2010} & E. coli & 11 & $2(18)$ \\
\hline & K. pneumoniae & 5 & $3(60)$ \\
\hline & Klebsiella spp. & 9 & - \\
\hline \multirow{3}{*}{2011} & E. coli & 6 & $3(50)$ \\
\hline & K. pneumoniae & 11 & $7(64)$ \\
\hline & Klebsiella spp. & 7 & $2(29)$ \\
\hline \multirow{3}{*}{2012} & E. coli & 12 & $4(33)$ \\
\hline & K. pneumoniae & 14 & $7(50)$ \\
\hline & Klebsiella spp. & 1 & - \\
\hline \multirow{3}{*}{2013} & E. coli & 14 & $9(64)$ \\
\hline & K. pneumoniae & 33 & $3(9)$ \\
\hline & Klebsiella spp. & 1 & $1(100)$ \\
\hline \multirow{3}{*}{2014} & E. coli & 15 & $7(47)$ \\
\hline & K. pneumoniae & 50 & $20(40)$ \\
\hline & Klebsiella spp. & 3 & 0 \\
\hline \multirow{3}{*}{2015} & E. coli & 11 & $7(64)$ \\
\hline & K. pneumoniae & 66 & $23(35)$ \\
\hline & Klebsiella spp. & 1 & - \\
\hline \multirow{3}{*}{2016} & E. coli & 11 & $4(36)$ \\
\hline & K. pneumoniae & 48 & $17(35)$ \\
\hline & Klebsiella spp. & 2 & $2(100)$ \\
\hline \multirow{3}{*}{2017} & E. coli & 13 & $3(23)$ \\
\hline & K. pneumoniae & 66 & $14(21)$ \\
\hline & Klebsiella spp. & 2 & - \\
\hline \multirow{3}{*}{2018} & E. coli & 25 & $9(36)$ \\
\hline & K. pneumoniae & 95 & $24(25)$ \\
\hline & Klebsiella spp. & 4 & - \\
\hline
\end{tabular}

The first three NI types vary in studies from different regions of Turkey $(14,19,20,21,22)$. In our study, in order of frequency, the most common NI was VAP (34.1\%), followed by CAUTI $(21.8 \%)$, primary bacteremia (17.1\%), CRBSI $(14.7 \%)$ and pneumonia $(8.5 \%)$.

The causative microorganisms in NI may differ between hospitals and in-hospital units, as well as vary according to the systems in which they are infectious. Gram negative bacteria are the most common agents in VAP and urinary tract infections. Grampositive bacteria are more frequent agents in bloodstream and surgical site infections $(9,23)$. In our study, the most common agents in VAP and urinary tract infections were gram negative bacteria, primarily Acinetobacter spp. While gram-negative bacteria were detected as the causative agent in $57.2 \%$ of all NIs in 2010, this rate increased over the years and reached $86.7 \%$ 
Table 6. Antimicrobial resistance of gram-negative bacteria causing nosocomial Infection between 2010-2018 in ICUs

\begin{tabular}{|c|c|c|c|c|c|c|c|c|}
\hline \multicolumn{9}{|c|}{ Resistance (\%) } \\
\hline 2010 & 2011 & 2012 & 2013 & 2014 & 2015 & 2016 & 2017 & 2018 \\
\hline 81 & 100 & 100 & 98 & 98 & 78 & 100 & 100 & 100 \\
\hline 95 & 79 & 97 & 96 & 97 & 92 & 98 & 75 & 99 \\
\hline 100 & 100 & 100 & 100 & 100 & 100 & 100 & 100 & 100 \\
\hline 95 & 97 & 98 & 99 & 100 & 100 & 100 & 100 & 100 \\
\hline- & - & - & & - & 2 & 1 & 1 & 2 \\
\hline 24 & 20 & 67 & 57 & 21 & 9 & 44 & 38 & 70 \\
\hline 41 & 10 & 47 & 38 & 15 & 3 & 23 & 24 & 64 \\
\hline 100 & 100 & 100 & 100 & 100 & 100 & 100 & 100 & 100 \\
\hline 48 & 20 & 74 & 56 & 25 & 3 & 28 & 28 & 74 \\
\hline- & - & - & - & - & 1 & - & 2 & - \\
\hline 30 & 60 & 43 & 52 & 55 & 76 & 81 & 82 & 87 \\
\hline 50 & 41 & 57 & 48 & 7 & 6 & 76 & 48 & 36 \\
\hline 100 & 82 & 86 & 75 & 34 & 50 & 85 & 57 & 74 \\
\hline 60 & 65 & 79 & 78 & 47 & 55 & 98 & 71 & 96 \\
\hline - & - & - & - & - & 1 & 3 & 10 & 34 \\
\hline
\end{tabular}

ICUs: Intensive care units

Table 7. Vancomycin resistance in causative enterococci in ICUs between 2010-2018

\begin{tabular}{|l|l|l|}
\hline & Number of agents & Number of agents resistant to vancomycin (\%) \\
\hline 2010 & 13 & 0 \\
\hline 2011 & 18 & $2(11)$ \\
\hline 2012 & 13 & $3(23)$ \\
\hline 2013 & 13 & $3(23)$ \\
\hline 2014 & 35 & $3(9)$ \\
\hline 2015 & 25 & $3(12)$ \\
\hline 2016 & 16 & $5(31)$ \\
\hline 2017 & 19 & - \\
\hline 2018 & 25 & $1(4)$ \\
\hline ICUs: Intensive care units & & \\
\hline
\end{tabular}

in 2018. In the "European Prevalence of Infection in Intensive Care (EPIC II)" study, which examined data from 1265 ICUs from 75 countries, $62 \%$ of the causative microorganisms were gram negative bacteria, $47 \%$ gram-positive bacteria and $19 \%$ candida (24). In a study conducted in Brazil, it was found that gram negative bacteria were causative agents in $28.1 \%$ of NIs, gram positive bacteria in $7.8 \%$, and fungi in $1.6 \%(25) .7$

In two separate studies conducted by Küçükbayrak et al. (26) and Tanriverdi Çaycı et al. (27), the most frequently isolated NI agents were P. aeruginosa and Acinetobacter spp. In the study of Kiremitçi et al. (11) the most frequently isolated microorganisms in the ICU were Acinetobacter spp. (28.4\%), S. aureus (19.8\%), Candida spp. (13.4\%) and $P$. aeruginosa (8.1\%). The most common gram negative bacteria isolated in our study were Acinetobacter spp. (30\%), followed by Klebsiella spp. (15.2\%), Pseudomonas spp. (14.4\%), and E.coli (4.2\%). Of Gram-positive bacteria, $5.3 \%$ were coagulase negative staphylococcus (CNS),
2.1\% S.aureus, and 6.2\% Enterococcus spp. Candida was observed at a rate of $13 \%$. For this reason, empirical antibiotic should be chosen to cover gram-negative bacteria first in infections occurring in the ICU.

Studies have shown that methicillin resistance rate in staphylococci detected as infectious agents in ICUs, vancomycin resistance rate in enterococci and carbapenem resistance rate in gram negative bacteria are higher than those found in other parts of the hospital $(9,22,28,29,30)$. In our study, carbapenem resistance in ICU was detected as $33 \%$ in 2010 , but it gradually increased over the years and reached $75 \%$ in 2018. Especially, very high $(90-100 \%)$ carbapenem resistance in A. baumannii strains has been interpreted as a result of intensive use of carbapenem against resistant gram-negative bacteria in ICUs in recent years. Similarly, the high rate of resistance to methicillin in coagulase-negative staphylococci and the use of glycopeptides in the treatment of infections caused by these bacteria cause the 
risk of vancomycin resistance in gram positive bacteria. When the enterococcus strains included in our study were evaluated; vancomycin resistance was found in $11.2 \%$.

Colistin resistance rates have increased in recent years as Acinetobacter-induced infection rates and colistin use have increased in ICUs. In our study, it was found that colistin resistance reached 2\% in Acinetobacter and Pseudomonas and up to $34 \%$ in Klebsiella spp.

It has been reported that antibiotic resistance in microorganisms can be minimized with the proper and appropriate use of antibiotics in ICUs (31). In their study, Gruson et al. reported that providing the correct use of antibiotics in the ICU reduced the rate of VAP and resistant microorganisms (32).

With the use of antibiotics in combinations and sequentially, developmet of new resistance can be reduced. The choice of drugs to be used can be made depending on the microbiological flora detected in the ICU. To prevent microorganisms to develop resistance; unnecessary antibiotic use should be avoided, antibiotics should be used in appropriate dose and time according to the detected microorganism and the focus of infection, appropriate antibiotic combinations in empirical treatment should be selected for the microorganisms previously detected in the ICU, and appropriate isolation methods should be applied to patients who have developed NI caused by multi-drug resistant microorganisms. After empirical treatment, the treatment should be rearranged according to the agent reproducing.

\section{Conclusion}

As a result, NIs developing in ICUs are an important problem in our country as in the whole world. Many factors play a role in controlling NI. It is very important knowing the situations where hand washing is necessary, avoiding unnecessary antibiotic use, obeying the isolation rules, paying attention to the hospital cleaning rules, performing disinfection and sterilization processes properly and regularly, and performing surveillance studies properly. Surveillance studies help to reduce hospital infection rates, identify hospital outbreaks, and compare hospital infection rates. For this reason, all hospitals should know the factors causing NI and their sensitivity profiles; thus will contribute to the selection of appropriate antibiotics in empirical treatment, to decrease the unnecessary use of antibiotics, to decrease the cost and to prevent the emergence of resistant agents.

\section{Ethics}

Ethics Committee Approval: The study was approved by the Antalya Training and Research Hospital Ethics Committee (Date: 30-03-2017, number: 6/03).

Peer-review: Internally peer reviewed.

\section{Authorship Contributions}

Concept: A.K.S., F.K., K.D.Ö., N.Ö., Design: A.K.S., F.K., K.D.Ö., N.Ö., Data Collection or Processing: A.K.S., F.K., K.D.Ö., N.Ö., Analysis or Interpretation: A.K.S., F.K.,
K.D.Ö., N.Ö., Literature Search: A.K.S., F.K., K.D.Ö., N.Ö., Writing: A.K.S., F.K., K.D.Ö., N.Ö.

Conflict of Interest: No conflict of interest was declared by the authors.

Financial Disclosure: The authors declared that this study received no financial support.

\section{References}

1. Ertürk A, Çopur Çiçek A, Köksal E, Şentürk Köksal Z, Özyurt S. Yoğun bakım ünitesinde yatan hastaların çeşitli klinik örneklerinden izole edilen mikroorganizmalar ve antibiyotik duyarlılıkları. ANKEM Derg 2012;26:1-9.

2. CDC. CDC/NHSN Surveillance Definitions for Specific Types of Infections. Available from: URL: https://www.cdc.gov/nhsn/pdfs/ pscmanual/17pscnosinfdef_current.pdf

3. Genç Y, Gürkan Y, Mumcuoğlu İ, Kanyılmaz D, Aksoy A, Aksu N. Evaluation of nosocomial pneumoniae in intencive care unit patients and investigation of antimicrobial resistance of frequently encountered bacterial isolates. Turk Hij Den Biyol Derg 2016;73:355-64.

4. Tunger O, Karakaya Y, Çetin BC, Dinç G, Borand H. Rational antibiotic use. J Infect Dev Ctries 2009;3:88-93.

5. Çıragil P. Ülkemizde Yoğun Bakım Ünitelerinde Antimikrobiyal Direnç Sorunu. Türk Mikrobiyol Cem Derg 2016;46:97-104.

6. Chaturvedi D, Jena PP, Tarai B, Sandhu K. Infections in Neurosurgical Intensive Care patients: A 3-Year Study in a Tertiary Health Care Center, North India. JNACC 2019;6:030-6.

7. Erol S. Hastane enfeksiyonları sürveyansı. İ.Ü. Cerrahpaşa Tıp Fakültesi Sürekli Tıp Eğitimi Etkinlikleri Hastane Enfeksiyonları: Korunma ve Kontrol Sempozyum Dizisi. 2008:43-51.

8. Wang L, Zhou KH, Chen W, Yu Y, Feng SF. Epidemiology and risk factors for nosocomial infection in the respiratory intensive care unit of a teaching hospital in China: A prospective surveillance during 2013 and 2015. BMC Infect Dis 2019;19:145.

9. Küçükateş E, Kocazeybek B. İstanbul Üniversitesi Kardiyoloji Enstitüsü Yoğun Bakım ünitelerinde yatan hastalardan izole edilen bakteriler ve antibiyotik duyarlılıkları. Türk Mikrobiyol Cem Derg 2001;31:19-22.

10. Yılmaz N, Köse Ş, Ağuş N, Ece G, Akkoçlu G, Kıraklı C. Yoğun bakım ünitesinde yatan hastaların kan kültürlerinde üreyen mikroorganizmalar, antibiyotik duyaklılıkları ve nozokomiyal bakteriyemi etkenleri. ANKEM Derg 2010;24:12-9.

11. Kiremitçi A, Durmaz G, Akgün Y, Kiraz N, Aybey A, Yelken B. Anestezi yoğun bakım ünitesinde çeşitli klinik örneklerden üretilen mikroorganizmalar ve antibiyotik direnç profilleri: 2003 yılı verileri. İnfeks Derg 2006;20:37-40.

12. Trilla A. Epidemiology of nosocomial infections in adult intensive care units, Intensive Care Med 1994;20(Suppl 3):S1-4.

13. Akalın $H$. Infections in intensive care units: risk factors and epidemiology. Turkish J Hosp Infect 2001:5:5-16.

14. Karahocagil MK, Yaman G, Göktaş U, Sünnetçioğlu M, Çıkman A, Bilici A, et al. Hastane enfeksiyon etkenlerinin ve direnç profillerinin belirlenmesi. Van Tip Derg 2011:18:27-32. 
15. Öncül A, Koçulu S, Elevli K. Bir devlet hastanesinin yoğun bakım ünitelerinde kazanılan hastane enfeksiyonlarının epidemiyolojisi. Med Bull Sisli Etfal 2012;46:60-6.

16. Barcenilla F, Gasco E, Rello J, Alvarez-Rocha L. Antibacterial treatment of invasive mechanical ventilation- associated pneumonia. Drugs Aging 2001;18:189-200.

17. Akça O, Koltka K, Uzel S, Cakar N, Pembeci K, Sayan MA, et al. Risk factors for early-onset, ventilator-associated pneumonia in critical care patients: selected multiresistant versus nonresistant bacteria. Anesthesiology 2000;93:638-45.

18. Akın A, Esmaoğlu Çoruh A, Alp E, Günay Canpolat D. Anestezi yoğun bakım ünitesinde beş yıl içerisinde gelişen nozokomiyal enfeksiyonlar ve antibiyotik direncinin değerlendirilmesi. Erciyes Tip Derg 2011;33:7-16.

19. Otkun M, Akata F, Teker B, Aka F, Otkun TM, Tuğrul M, et al. Trakya Üniversitesi Hastanesinde hastane infeksiyonları: 1995 yılı sonuçları. İnfeks Derg 1997;11:23-7.

20. Görenek L, Beşirbellioğlu B, Gül C, Tabak F, Hacıbektaşoğlu A. GATA Eğitim Hastanesinde hastane infeksiyonu insidansı. Hastane İnfeksiyon Derg 1997;1:97-100.

21. Mamıkoğlu L, Günseren F, Özçelik FT, Saba R, Sarıgül F, Atakan P, et al. Akdeniz Üniversite Hastanesinde hastane infeksiyonları: 19941995. Hastane İnfeksiyon Derg 1998;2:42-5.

22. İnan D, Saba R, Keskin S, Öngüt G, Öğünç D, Günseren F, et al. Akdeniz üniversitesi hastanesi yoğun bakım ünitelerinde hastane enfeksiyonları sürveyansı: Alet kullanım ve alet ilişkili enfeksiyon oranları. Hastane İnfeks Derg 2004;8:50-6.

23. Öktem MA, Gülay Z, Ercan H, Biçmen M, Yuluğ N. Yoğun bakım ünitelerinden soyutlanan mikroorganizmalar ve antibiyotik duyarlılıkları. İnfeks Derg 2001;15:61-6.
24. Vincent JL, Rello J, Marshall J, Silva E, Anzueto A, Martin CD, et al. International study of the prevalence and outcomes of infection in intensive care units. JAMA 2009;302:2323-9.

25. Hespanhol LAB, Ramos SCS, Junior OCR, de Araujo TS, Martins $\mathrm{AB}$. Infection related to health care in an adult intensive care unit. Enfermeria global 2019:242-54.

26. Küçükbayrak A, Özdemir D, Şencan İ, Yavuz T, Behçet M, Erdoğan S. AİBÜ Düzce Tip Fakültesi Hastanesi'nde yoğun bakım enfeksiyonları: 2003 yılı sonuçları. Düzce Tıp Fak Derg 2004;3:15-9.

27. Tanrıverdi Çaycı Y, Bıyık İ, Birinci A. Yoğun Bakım Ünitelerinden İzole Edilen Nonfermentatif Gram Negatif Bakterilerin Antimikrobiyal Duyarlılıklarının Araştırılması. Türk Mikrobiyoloji Cemiyeti Dergisi 2015;45:170-4.

28. Özden M, Demirdağ K, Kalkan A, Kılıç SS. Yoğun bakım ünitelerinde izlenen ve hastane enfeksiyonu gelişen olgulardan izole edilen bakterilerin sıklığı ve antibiyotiklere karşı direnç durumları. İnfeks Derg 2003;17:179-83.

29. Eser KÖ, Kocagöz S, Ergin A, Altun B, Hasçelik G. Yoğun bakım ünitelerinde infeksiyon etkeni olan gram-negatif basillerin değerlendirilmesi. İnfeks Derg 2005;19:75-80.

30. Çolpan A, Güngör Ş, Baykam N, Dokuzoğuz B. Yoğun bakım ünitelerinden izole edilen Acinetobacter suşlarının antibiyotik direnç durumlarının araştırılması. İnfeks Derg 2002;16:55-8.

31. Kollef MH. Optimizing antibiotic therapy in the intensive care unit setting. Crit Care 2001;5:189-95.

32. Gruson D, Hilbert G, Vargas F, Valentino R, Bebear C, Allery A, et al. Rotation and restricted use of antibiotics in a medical intensive care unit. Am J Respir Crit Care Med 1999;162;837-43. 